\title{
Familiær forekomst av kronisk lymfatisk leukemi i Norge
}

\author{
Engelsk oversettelse på www.tidsskriftet.no
}

\begin{abstract}
Sammendrag
Bakgrunn. Kronisk lymfatisk leukemi (KLL) hos nære slektninger er den eneste kjente risikofaktoren for denne sykdommen. Hensikten med denne studien var å avklare hvor hyppig familiær sykdomsforekomst ved kronisk lymfatisk leukemi er.
\end{abstract}

Materiale og metode. Alle pasienter med kronisk lymfatisk leukemi meldt til Kreftregisteret i perioden 1.10. 2007-31.12. 2009 ble bedt om å angi forekomst av malign sykdom hos søsken, foreldre, besteforeldre og barn. Opplysningene om malign hematologisk sykdom ble verifisert i Kreftregisteret.

Resultater. Hos 42 av 236 inkluderte pasienter (18\%) påviste vi malign hematologisk sykdom hos nære slektninger. Kronisk lymfatisk leukemi og lymfom var de hyppigste diagnosene. Gjennomsnittlig ble 16 familiemedlemmer identifisert i hver familie. Den relative risikoen for å utvikle kronisk lymfatisk leukemi var seks ganger høyere hos dem som hadde nære slektninger med sykdommen (16 tilfeller blant 3776 familiemedlemmer) enn hos dem som ikke hadde nære slektninger som var rammet 176 tilfeller blant 107223 familiemedlemmer til 38159 kontrollpersoner). Den økte sykdomsrisikoen var også knyttet til andre lymfoproliferative sykdommer. Ved patrilineær nedarving, men ikke ved matrilineær, fant vi en effekt av fødselsrekkefølgen - med affeksjon av yngre menn i søskenflokken, mens de eldste spares.

Fortolkning. Malign hematologisk sykdom er vanlig hos familiemedlemmer av pasienter med kronisk lymfatisk leukemi. Kronisk lymfatisk leukemi er vanligste sykdom, men pleiotropi er fremtredende.

\section{Geir E. Tjønnfjord}

geir.tjonnfjord@oslo-universitetssykehus.no Viggo Jønsson

Avdeling for blodsykdommer

Oslo Universitetssykehus

og

Institutt for klinisk medisin

Universitetet i Oslo

\section{Bernt E. Ly}

Tom Børge Johannesen

Kreftregisteret

Høyeste insidens for kronisk lymfatisk leukemi (KLL) finner vi i Europa og i befolkningsgrupper av europeisk herkomst ellers i verden (1). Lav insidens ses i Sør-Asia og Øst-Asia, med spesielt lav forekomst $\mathrm{i}$ den japanske befolkningen. Migrasjonsundersøkelser viser at insidensen forblir lav hos asiater, selv hos dem som er født $\mathrm{i}$ den vestlige verden og $\mathrm{i}$ senere generasjoner (2). Familiær forekomst av kronisk lymfatisk leukemi underbygger ytterligere at det dreier seg om en genetisk predisposisjon.

Familiær forekomst av kronisk lymfatisk leukemi ble første gang beskrevet av Videbæk i 1947 (3). Senere er hans observasjoner bekreftet i mer enn 100 familier (4). I en stor studie basert på det svenske leukemiregisteret var den relative risikoen for å utvikle kronisk lymfatisk leukemi 8,5 ganger høyere og risikoen for andre lymfoproliferative sykdommer 2,6 ganger høyere hos personer med en førstegradsslektning med kronisk lymfatisk leukemi enn i kontrollgruppen (2, $5,6)$. Vi har tidligere vist at det dreier seg om stor grad av pleiotropi når det gjelder sykdom hos nære slektninger til pasienter med kronisk lymfatisk leukemi (6). En engelsk tverrsnittsstudie viste at monoklonal B-lymfocytose kunne påvises hos $13,5 \%$ av 59 friske førstegradsslektninger til 21 pasienter med kronisk lymfatisk leukemi (7). Tidligere fantes det ingen studier der man hadde undersøkt hvor stor andel av pasientene som hadde nære familiemedlemmer med verifisert lymfoproliferativ eller myeloproliferativ sykdom.

Målet med den aktuelle studien var å avklare forekomst av malign hematologisk sykdom hos nære slektninger av pasienter med kronisk lymfatisk leukemi.

\section{Materiale og metode}

Pasientpopulasjon

Alle pasienter med kronisk lymfatisk leukemi i perioden 1.10. 2007-31.12. 2009 som ble meldt til Kreftregisteret, var inkluderbare i studien. Pasientene ble inkludert etter informert skriftlig samtykke. De etterspurte familieopplysningene ble, sammen med ordinær kreftmelding, sendt til Kreftregisteret, som fungerte som sekretariat for studien. I de tilfellene Kreftregisteret mottok melding om et nytt tilfelle av kronisk lymfatisk leukemi uten at pasienten var inkludert i studien, ble legen som hadde sendt kreftmeldingen, kontaktet med anmodning om å forespørre pasienten om inklusjon. Studien var et samarbeidsprosjekt mellom Norsk selskap for hematologi og Kreftregisteret, og artikkelforfatterne utgjorde studiens prosjektgruppe. Norske hematologer ble orientert om studien gjennom Norsk selskap for hematologi, og detaljert informasjon om studien var tilgjengelig på selskapets og på Kreftregisterets hjemmesider.

Studien var godkjent av regional komité for medisinsk forskningsetikk (REK S-06353b) og Datatilsynet (07/00254-2).

\section{Genealogisk kartlegging}

Pasientene fylte ut et spørreskjema der de ble bedt om å oppgi navn og fødselsdato/personnummer for søsken, foreldre, besteforeldre og barn og anføre forekomst av malign sykdom hos disse slektningene. Noen kom også med opplysninger om barnebarn, nevøer, nieser, onkler og tanter. Opplysningene om malign sykdom ble verifisert mot Kreftregisterets database eller ved å se i sykehusjournaler for dem som var døde før personnummer ble innført i Norge. Hos de slektningene der probanden ikke kunne bidra med opplysninger om malign sykdom, ble sykdomsforekomst undersøkt med Kreftregisterets database.

Bare familier hvor malign hematologisk sykdom hos medlemmer ble verifisert $\mathrm{i}$ Kreftregisteret, ble akseptert som slekt med slik sykdom. På bakgrunn av disse opplysningene ble det tegnet familiekart.

\section{Hovedbudskap}

- Malign hematologisk sykdom forekommer hyppig hos nære slektninger av pasienter med kronisk lymfatisk leukemi

- Sykdomsrisikoen er ikke begrenset til kronisk lymfatisk leukemi, men gjelder også andre maligne hematologiske sykdommer 


\section{Diagnostiske kriterier}

For å stille diagnosen kronisk lymfatisk leukemi var det nødvendig å dokumentere vedvarende klonal B-lymfocytose $\left(\geq 5 \cdot 10^{9} / 1\right)$ med en karakteristisk immunfenotype i henhold til de reviderte internasjonale retningslinjene fra International Workshop on Chronic Lymphocytic Leukemia (8). Småcellet lymfocyttært lymfom (SLL) skiller seg kun fra kronisk lymfatisk leukemi ved fravær av lymfocytose. Pasienter med klonal B-lymfocytose, men $<5 \cdot 10^{9} / 1$, lymkeknutesvulst og/eller splenomegali og histologisk bekreftelse av lymfeknute og/eller beinmargsaffeksjon ble inkludert under diagnosen småcellet lymfocyttært lymfom.

\section{Statistiske metoder}

Det er benyttet deskriptiv statistikk med angivelse av median, gjennomsnitt, spredning og ratio. Familiær sykdomsopphopning ble undersøkt ved å beregne relativ risiko for utvikle sykdom ved å være slektning av en proband mot det å være slektning av en kontrollperson. Vi har ikke identifisert noen egen kontrollgruppe, vi har lagt kontrollgruppen (76 tilfeller blant 107223 familiemedlemmer til 38159 kontrollpersoner) fra Goldin og medarbeidere til grunn for beregningene (5).

Vi tegnet detaljerte familietrær for hver av de 42 probandene for å avklare affiserte og friske familiemedlemmers plass i søskenflokken i mors familie og i fars familie. Haldane-Smiths test for betydning av fødselsrekkefølgen ble benyttet, og gjennomsnittlig rangering i søskenflokken etter alder ble beregnet med utgangspunkt i hver enkelt proband (9).

\section{Resultater}

Pasienter

I studieperioden ble det meldt 388 nye tilfeller av kronisk lymfatisk leukemi til Kreftregisteret. 236 av disse pasientene $(61 \%)$ samtykket i å delta i studien og fylte ut spørreskjemaet med opplysninger om slekten. Vi vet ikke hvor mange som ble spurt om å delta og avslo.

\section{Familiær forekomst}

av malign hematologisk sykdom

Familiær forekomst av malign hematologisk sykdom ble bekreftet hos 42 probander $(18 \%)$. Ytterligere fem la frem opplysninger om malign hematologisk sykdom hos nære familiemedlemmer, men vi klarte ikke å verifisere opplysningene ved hjelp av Kreftregisterets database, heller ikke ved hjelp av sykehusjournaler. Disse fem ble derfor ikke inkludert som familier med malign hematologisk sykdom.

Hos i alt 60 familiemedlemmer i 42 familier verifiserte vi malign blodsykdom (tab 1$)$. I familien til 28 av probandene $(67 \%)$ var det ett annet affisert medlem, og i 14 familier $(33 \%)$ var det flere. I 31 av familiene $(74 \%)$ fant vi kun lymfoproliferativ sykdom, mens vi i 11 familier (26\%) fant en kombinasjon av lymfoproliferativ og myeloproliferativ sykdom (inkluderer uspesifisert leukemi).

I de to familiene med flest affiserte familiemedlemmer fant vi til sammen ti personer med malign hematologisk sykdom, inkludert probandene, og det var affiserte familiemedlemmer både på mors og på fars side $\mathrm{i}$ den ene familien. Det var mer enn én sykdomskombinasjon for probander med flere affiserte familiemedlemmer ( $\operatorname{tab} 2$ ). De affiserte familiemedlemmene hadde flere ulike hematologiske maligniteter, men kronisk lymfatisk leukemi var den klart hyppigste enkeltsykdommen (27\%). Non-Hodgkins lymfom forekommer like hyppig (28\%), men samlebetegnelsen non-Hodgkins lymfom favner flere enkeltdiagnoser. KLL/ KLL-proband-forelder-par utgjør bare $35 \%$ av de 17 proband-forelder-parene (tab 2).

Det er jevn fordeling av maternell og paternell arv (29 nedarvinger på mors side og 23 på fars side) og overvekt av affiserte menn sammenliknet med affiserte kvinner, både blant probandene (26 menn og 16 kvinner, ratio 1,63$)$ og blant affiserte slektninger $(41$ menn og 19 kvinner, ratio 2,16). Ved forstegenerasjonsnedarving er det utelukkende kvinnelige affiserte slektninger ved matrilineær arv og utelukkende mannlige affiserte slektninger ved patrilineær arv ( $\operatorname{tab} 2)$.

\section{Alder, $V_{H^{-}}$genbruk,}

fødselsrekkefølge og sykdomsrisiko

Median alder hos de 42 probandene var 62 år (gjennomsnittsalder 61,9 år, spredning 40-86 år)

Molekylærgenetisk undersøkelse for å avklare hvilket gen som kodet for den variable delen av immunglobulinets tunge kjede hos KLL-cellene (foretrukket $\mathrm{V}_{\mathrm{H}^{-} \text {-gen) og }}$ om $\mathrm{V}_{\mathrm{H}}$-genet hadde gjennomgått somatisk hypermutasjon eller ikke (mutasjonsstatus) var vellykket hos 39 probander. De hyppigst foretrukne $\mathrm{V}_{\mathrm{H}}$-genene hos disse pasientene var de samme som vi fant hyppigst hos de øvrige inkluderte pasientene $-\mathrm{V}_{\mathrm{H}} 1-69$ hos fire pasienter, $\mathrm{V}_{\mathrm{H}} 3-7$ hos fire, $\mathrm{V}_{\mathrm{H}} 3-23$ hos tre, $\mathrm{V}_{\mathrm{H}} 3-30$ hos fem og $\mathrm{V}_{\mathrm{H}} 4-34$ hos fire. Hos 23 probander $(59 \%)$ var det foretrukne
Tabell 1 Malign hematologisk sykdom fordelt på diagnose hos 60 familiemedlemmer ti 42 probander med kronisk lymfatisk leukemi

Diagnose

Antall

Lymfoproliferative sykdommer personer

Kronisk lymfatisk leukemi

Non-Hodgkins lymfom

46

16

17

Hodgkins lymfom

Akutt lymfoblastisk leukemi

Hårcelleleukemi

Myelomatose

Myeloproliferative sykdommer

Akutt myelogen leukemi

Kronisk myelogen leukemi

Myeloid leukemi, uspesifisert

Uspesifisert leukemi

$\mathrm{V}_{\mathrm{H}}$-genet mutert, hos 16 probander $(41 \%)$ var det foretrukne $\mathrm{V}_{\mathrm{H}}$-genet umutert. Fem probander $(13 \%)$ hadde biallelisk kronisk lymfatisk leukemi, dvs. KLL-cellene benyttet to $\mathrm{V}_{\mathrm{H}}$-gener.

Hos 36 probander (19 med patrilineær og 17 med matrilineær nedarving) var det affeksjon på én side av familien, mens det hos seks probander var malign hematologisk sykdom på begge sider. Fødselsrekkefølgen for den affiserte i søskenflokken var forskjellig avhengig av om det var snakk om sykdom i mors familie eller i fars (tab 3 ). Når disposisjon for kronisk lymfatisk leukemi ble nedarvet fra fars side (patrilineær arv), var den syke aldri den eldste i søskenflokken, mens den syke befant seg helt tilfeldig i søskenflokken dersom disposisjonen for kronisk lymfatisk leukemi kom fra mors side (matrilineær arv). Det var ingen forskjell i kjønnsfordeling i søskenflokkene mellom matrilineær og partrilineær arv.

Vi identifiserte gjennomsnittlig 16 slektninger (spredning 6-33) i hver familie. På basis av dette har vi beregnet relativ risiko for kronisk lymfatisk leukemi hos nære slektnin-

Tabell 2 Malign hematologisk sykdom hos 60 familiemedlemmer til 42 probander med kronisk lymfatisk leukemi og familiemedlemmenes slektsforhold til probandene

\begin{tabular}{llccc} 
Slektsforhold til proband & Kjønnsfordeling & $\begin{array}{c}\text { Mor/morssiden } \\
\text { Antall }\end{array}$ & $\begin{array}{c}\text { Far/farssiden } \\
\text { Antall }\end{array}$ & $\begin{array}{c}\text { Søsken } \\
\text { Antall }\end{array}$ \\
\hline Foreldre & $M / K=11 / 6$ & 9 & 8 & \\
\hline Barn & $M / K=0 / 1$ & 1 & & \\
\hline $\begin{array}{l}\text { Besteforeldre } \\
\text { Barnebarn }\end{array}$ & $M / K=7 / 1$ & 5 & 3 & \\
$\begin{array}{l}\text { Øvrige andre- } \\
\text { og tredjegradsslektninger }\end{array}$ & $M / K=1 / 0$ & 1 & & 8 \\
$\begin{array}{l}\text { Søsken } \\
\text { M }\end{array}$ & $M / K=17 / 8$ & 13 & & $8 / 3$ \\
& Totalt $M / K=41 / 19$ & $M / K=10 / 19$ & $M / K=19 / 4$ & $M / K=3 / 5$
\end{tabular}




\begin{tabular}{|c|c|c|c|c|c|}
\hline Arv & Antall probander & $\begin{array}{l}\text { Skår for aldersbestemt } \\
\text { rangorden av søsken med } \\
\text { malign hematologisk sykdom } \\
\text { (gjennomsnitt) }\end{array}$ & $\begin{array}{l}95 \% \mathrm{KI} \text { hvis det ikke er alders- } \\
\text { bestemt rangorden av søsken } \\
\text { med malign hematologisk } \\
\text { sykdom }\end{array}$ & $\begin{array}{l}\text { Størrelse på søsken- } \\
\text { flokken (gjennomsnitt) }\end{array}$ & P-verdi \\
\hline Patrilineær & 19 & 288 & $192-282$ & 2,9 & 0,02 \\
\hline Matrilineær & 17 & 216 & $186-278$ & 2,9 & 0,7 \\
\hline
\end{tabular}

ger til pasienter med sykdommen (16 tilfeller blant 3776 familiemedlemmer) sammenliknet med kontrollgruppen. Vi fant seks ganger økt risiko for kronisk lymfatisk leukemi for familiemedlemmer av personer med sykdommen sammenliknet med risikoen for dem uten denne sykdommen i familien.

\section{Diskusjon}

Vi har i denne studien identifisert familiemedlemmer i inntil fem generasjoner hos 236 pasienter med kronisk lymfatisk leukemi, og vi fant at 42 probander $(18 \%)$ hadde nære familiemedlemmer med malign hematologisk sykdom. Så langt vi kjenner til er dette første gang familiær forekomst av malign hematologisk sykdom er kartlagt med genealogisk metodikk blant pasienter med kronisk lymfatisk leukemi rekruttert i en populasjonsbasert studie. Ved slik metodikk har vi kunnet identifisere langt flere nære slektninger enn det som har vært tilfellet i registerbaserte studier $(5,10-15)$.

I den største registerstudien, som omfattet 9717 svenske pasienter med kronisk lymfatisk leukemi, var det kun 29947 førstegradsslektninger som ble identifisert, dvs. tre for hver pasient (5). Vi identifiserte fem ganger flere slektninger per proband. Dette kan være noe av forklaringen til at vi fant malign hematologisk sykdom hos nesten dobbelt så mange nære slektninger av pasientene enn det man har funnet i tidligere studier $(18 \%$ versus $10 \%$ ) (4). Vi har ekskludert familier hvor vi ikke har kunnet verifisere opplysningene om sykdom blant slektningene i Kreftregisteret, selv om det var overveiende sannsynlig at opplysningene var korrekte. Det kan være seleksjonsskjevhet $i$ vårt materiale, siden bare $61 \%$ av dem som fikk diagnostisert kronisk lymfatisk leukemi i studieperioden ble inkludert i studien.

Goldin og medarbeidere fant, i likhet med oss, at den økte risikoen for å utvikle malign sykdom hos førstegradsslektninger til pasienter med kronisk lymfatisk leukemi ikke var begrenset til denne sykdommen, men også omfattet andre lymfoproliferative sykdommer av B-celletype (5). De fant at den relative risikoen for å utvikle kronisk lymfatisk leukemi var 8,5 ganger høyere enn i kontrollpopulasjonen, vi fant at den var seks ganger høyere.

At vi finner en noe lavere relativ risiko for kronisk lymfatisk leukemi har sannsynligvis sammenheng med at vi har kunnet identifi- sere langt flere nære slektninger (16 slektninger/familie) enn man har kunnet $i$ de registerbaserte studiene (tre slektninger/familie) (5). Vårt estimat er dessuten et minimumstall fordi flere av familiemedlemmene naturligvis ikke har vært fulgt lenge nok til å utelukke at de kan utvikle kronisk lymfatisk leukemi i løpet av livet. I det svenske materialet var det et relativt langt observasjonsvindu med mulighet for sykdomsutvikling hos slektningene (kronisk lymfatisk leukemi diagnostisert i perioden 1958-2004).

Våre data indikerer at sannsynligheten for å finne førstegradsslektninger til pasienter med kronisk lymfatisk leukemi som har annen lymfoproliferativ sykdom er større enn sannsynligheten for å finne slektninger med kronisk lymfatisk leukemi. Dette er helt i tråd med Goldin og medarbeideres data, men fordi annen lymfoproliferativ sykdom forekommer betydelig hyppigere enn kronisk lymfatisk leukemi, blir den relative risikoen lavere (RR 2,6) (5). Det er en svakhet ved vår studie at vi ikke har hatt et norsk kontrollmateriale, men vi har vist at insidensen av kronisk lymfatisk leukemi i Norge er den samme som ellers i Skandinavia og i den vestlige verden for øvrig (16).

Det finnes to tidligere studier der man har sammenliknet klinisk fenotype ved familiær og sporadisk kronisk lymfatisk leukemi (17, 18). Stadium ved diagnosetidspunktet, behandlingsbehov og overlevelse var sammenliknbare, men mannsdominansen syntes å være utvisket ved familiær kronisk lymfatisk leukemi. Forklaringen skulle være at kvinner i større grad enn menn med kronisk lymfatisk leukemi skulle ha en genetisk predisposisjon for sykdommen (19). I vår studie ser vi også tegn til dette. I proband-foreldrekombinasjonen er det like mange affiserte mannlige som kvinnelige slektninger, men det er en markant assosiasjon mellom kvinner og matrilineær arv og menn og patrilineær arv ( $\operatorname{tab} 2)$.

Ut fra tidligere studier har det vært antydet at det er lavere alder ved diagnosetidspunktet ved familiær kronisk lymfatisk leukemi enn ved sporadisk sykdom (20). I tråd med dette fant vi en noe lavere gjennomsnittsalder ved diagnosetidspunktet ved familiær sykdom (61,9 år) enn i hele materialet (65,9 år) (16), men andre har på en overbevisende måte vist at dette er en skjevhet som først og fremst skyldes at neste generasjon har kortere oppfølgingstid enn foreldregenerasjonen (5). En helt annen sak er at hos forelder-barn-par med kronisk lymfatisk leukemi er alder ved diagnosetidspunktet høyere hos foreldrene enn hos barna. Det har vært tatt til inntekt for antesipasjonshypotesen (tidligere sykdomsdebut og alvorligere sykdomsmanifestasjon i påfølgende generasjoner), men $\mathrm{i}$ våre tidligere studier har vi ikke funnet statistisk belegg for hypotesen (21).

Våre tidligere observasjoner indikerer at familiær predisposisjon for kronisk lymfatisk leukemi resulterer i en uttalt pleiotropi når det gjelder sykdomsmanifestasjoner hos familiemedlemmene (6). Dette er i tråd med Goldin og medarbeideres studier $(5,12)$, og det bekreftes av den aktuelle studien. Våre observasjoner når det gjelder alder, $\mathrm{V}_{\mathrm{H}}$-genbruk og kjønnsfordeling er argumenter for at familiær kronisk lymfatisk leukemi ikke skiller seg fra sporadisk kronisk lymfatisk leukemi (16). Denne oppfatningen understøttes av andre studier $(17,18)$.

Det molekylære grunnlaget for sårbarhet for kronisk lymfatisk leukemi er ikke klarlagt fullt ut, men det er påvist 7-8 genloci som er assosiert med økt sårbarhet for sykdommen og dens pleiotypier. De sykdomspredisponerende loci som så langt er klarlagt, er knyttet til gener som koder for immunregulatoriske proteiner (22). Arvegangen er ikke sikkert fastlagt, men det synes å være en kompleks nedarving som ikke følger tradisjonelle arvemønstre. Vi viser $i$ denne studien at $i$ alle fall ved patrilineær arv synes sårbarheten for kronisk lymfatisk leukemi og andre lymfoproliferative sykdommer å bli overført til de yngre mennene i søskenflokken. Dette bekrefter våre tidligere funn gjort $i$ annen kohort (21).

Kronisk lymfatisk leukemi kan betraktes som en genetisk sykdom med familiær og etnisk opphopning og med ulik og kjønnsavhengig penetrans. Dagens oppfatning er at sykdomsdisponerende varianter av sårbarhetsloci hver for seg bidrar i beskjeden grad (oddsratio $<1,5$ ), men de forekommer hyppig, i alle fall i den kaukasiske befolkningen, og hver pasient har flere sykdomsdisponerende varianter $(19,23-25)$. 


\section{Geir E. Tjønnfjord (f. 1953)}

er avdelingsleder for Avdeling for blodsykdommer, Oslo universitetssykehus, og professor i hematologi ved Institutt for klinisk medisin, Universitetet i Oslo. Han er spesialist i indremedisin og blodsykdommer.

Forfatter har fylt ut ICMJE-skjemaet og oppgir ingen interessekonflikter.

\section{Viggo Jønsson (f. 1948)}

er overlege ved Avdeling for blodsykdommer, Oslo universitetssykehus, og professor i hematologi ved Institutt for klinisk medisin, Universitetet i Oslo. Han er spesialist i indremedisin og blodsykdommer.

Forfatter har fylt ut ICMJE-skjemaet og oppgir ingen interessekonflikter.

\section{Bernt E. Ly (f. 1936)}

er tidligere avdelingsoverlege ved Avdeling for hematologi, Aker universitetssykehus. Han er spesialist $\mathrm{i}$ indremedisin og blodsykdommer. Forfatter har fylt ut ICMJE-skjemaet og oppgir ingen interessekonflikter.

\section{Tom Børge Johannesen (f. 1965)}

er nestleder ved Avdeling for klinisk forskning, Kreftregisteret. Han er spesialist i onkologi. Forfatter har fylt ut ICMJE-skjemaet og oppgir ingen interessekonflikter.

Artikkelen er skrevet på vegne av norsk KLLstudiegruppe.

\section{Litteratur}

1. Sgambati MT, Linet MS, Devesa SS. Chronic lymphocytic leukemia. Epidemiological, familial and genetic aspects. I: Cheson BD, red. Chronic lym- phoid leukemias. New York: Marcel Dekker, 2001 33-62.

2. Gale RP, Cozen W, Goodman MT et al. Decreased chronic lymphocytic leukemia incidence in Asians in Los Angeles County. Leuk Res 2000; 24: 665-9.

3. Videbæk A. Familial leukemia. A preliminary report. Acta Med Scand 1947; 127: 26-52

4. Yuille MR, Matutes E, Marossy A et al. Familial chronic lymphocytic leukaemia: a survey and review of published studies. $\mathrm{Br} \mathrm{J}$ Haematol 2000; 109: 794-9.

5. Goldin LR, Björkholm M, Kristinsson SY et al. Elevated risk of chronic lymphocytic leukemia and other indolent non-Hodgkin's lymphomas among relatives of patients with chronic lymphocytic leukemia. Haematologica 2009; 94: 647-53.

6. Jønsson V, Tjønnfjord GE, Johannesen TB et al. Familial chronic lymphocytic leukemia in Norway and Denmark. Comments on pleiotropy and birth order. In Vivo 2010; 24: 85-95.

7. Rawstron AC, Yuille MR, Fuller J et al. Inherited predisposition to CLL is detectable as subclinical monoclonal B-lymphocyte expansion. Blood 2002 100: 2289-90.

8. Hallek M, Cheson BD, Catovsky D et al. Guidelines for the diagnosis and treatment of chronic lymphocytic leukemia: a report from the International Workshop on Chronic Lymphocytic Leukemia updating the National Cancer Institute-Working Group 1996 guidelines. Blood 2008; 111: 5446-56.

9. Emery AEH. Parental age and birth order. I: Emery $A E H$, red. Methodology in medical genetics. 2. utg Edinburgh: Churchill Livingstone, 1986: 40-53.

10. Cannon-Albright LA, Thomas A, Goldgar DE et al. Familiality of cancer in Utah. Cancer Res 1994; 54: $2378-85$.

11. Goldin LR, Pfeiffer RM, Gridley $G$ et al. Familial aggregation of Hodgkin lymphoma and related tumors. Cancer 2004; 100: 1902-8.

12. Goldin LR, Pfeiffer RM, Li X et al. Familial risk of lymphoproliferative tumors in families of patients with chronic lymphocytic leukemia: results from the Swedish Family-Cancer Database. Blood 2004: 104: $1850-4$

13. Kerber RA, O'Brien E. A cohort study of cancer risk in relation to family histories of cancer in the Utah population database. Cancer 2005: 103: 1906-15.

14. Goldin LR, Landgren O, McMaster ML et al. Familial aggregation and heterogeneity of non-Hodgkin lymphoma in population-based samples. Cancer Epidemiol Biomarkers Prev 2005; 14: 2402-6.

15. Kristinsson SY, Björkholm M, Goldin LR et al.
Risk of lymphoproliferative disorders among first-degree relatives of lymphoplasmacytic lymphoma/Waldenstrom macroglobulinemia patients: a population-based study in Sweden. Blood 2008. 112: 3052-6

16. Tjønnfjord GE, Ly B, Johannesen TB et al. Kronisk lymfatisk leukemi i Norge - insidens og prognose ved diagnosetidspunktet. Tidsskr Nor Legeforen 2012: 132: 2056-9.

17. Crowther-Swanepoel D, Wild R, Sellick $G$ et al. Insight into the pathogenesis of chronic lymphocytic leukemia (CLL) through analysis of IgVH gene usage and mutation status in familial CLL. Blood 2008; 111: 5691-3.

18. Mauro FR, Giammartini E, Gentile M et al. Clinica features and outcome of familial chronic lymphocytic leukemia. Haematologica 2006; 91: 1117-20.

19. Crowther-Swanepoel D, Houlston RS. Genetic variation and risk of chronic lymphocytic leukaemia. Semin Cancer Biol 2010; 20: 363-9.

20. Ishibe N, Sgambati MT, Fontaine $L$ et al. Clinical characteristics of familial B-CLL in the National Cancer Institute Familial Registry. Leuk Lymphoma 2001; 42: 99-108.

21. Jønsson V. Tjønnfjord G, Samuelsen SO et al. Birth order pattern in the inheritance of chronic lymphocytic leukaemia and related lymphoproliferative disease. Leuk Lymphoma 2007: 48: 2387-96.

22. Crowther-Swanepoel D, Mansouri M, Enjuanes A et al. Verification that common variation at $2 q 37.1$ 6p25.3, 11q24.1, 15q23, and 19q13.32 influences chronic lymphocytic leukaemia risk. Br J Haematol 2010: 150: 473-9.

23. Setlur SR, Ihm C, Tchinda J et al. Comparison of familial and sporadic chronic lymphocytic leukaemia using high resolution array comparative genomic hybridization. Br J Haematol 2010; 151 $336-45$.

24. Conde L, Halperin E, Akers NK et al. Genome-wide association study of follicular lymphoma identifies a risk locus at 6p21.32. Nat Genet 2010: 42: 661-4.

25. Jønsson V, Tjønnfjord GE, Johannesen TB et al. Possible imprinting and microchimerism in chronic lymphocytic leukemia and related lymphoproliferative disorders. Transl Oncogenomics 2008; 3: $15-20$

Mottatt 29.11. 2011, første revisjon innsendt 9.4. 2012, godkjent 5.7. 2012. Medisinsk redaktør Trine B. Haugen. 